\title{
Loss of Maternal Allele in a Child With Myelodysplastic Syndrome and Monosomy 7
}

\author{
Dilek Aktas, ${ }^{1 *}$ Idıl Yenicesu, ${ }^{2}$ Gonul Hıcsonmez, ${ }^{2}$ and Ergul Tuncbilek ${ }^{1}$ \\ ${ }^{1}$ Department of Genetics, Hacettepe University, Insan Dogramacı Children's Hospital, 06100 Sıhhıye, Ankara, Turkey \\ 2Department of Hematology, Hacettepe University, Ihsan Dogramacı Children's Hospital, 06100 Sıhhıye, Ankara, Turkey
}

\begin{abstract}
Monosomy 7 or partial deletion of the long arm of chromosome 7 is frequently described in children with myelodysplastic syndrome and acute myeloblastic leukemia. Parental origin of chromosome 7 in children with sporadic monosomy 7 has been examined very rarely. To investigate if monosomy 7 shows parent-of-origin, we have studied a female child with monosomy 7 and de novo myelodysplastic syndrome by a series of polymorphic polymerase chain reaction markers. We found loss of maternal allele and discussed the results with the previous reports. Am. J. Hematol. 62:49-51, 1999.

() 1999 Wiley-Liss, Inc.
\end{abstract}

Key words: monosomy 7; myelodysplastic syndrome; parental origin

\section{INTRODUCTION}

Myelodysplastic syndromes (MDS) are clonal disorders of hematopoietic stem cells. These disorders have been described mainly in adults and it is rare in pediatric age groups [1,2]. MDS in children is often characterized by an aggressive clinical course and limited response to chemotherapy $[3,4]$. Monosomy 7 or partial deletion of long arm of chromosome 7 is one of the most common cytogenetic abnormalities in de novo MDS and acute myeloblastic leukemia (AML) [5,6]. In addition, monosomy 7 has been described in secondary disorders (therapy-related or occupational exposure) and constitutional disorders associated with a predisposition to leukemia (NF1, Down's syndrome, etc.) [5,7-10].

Monosomy 7 may play a significant role in leukemogenesis but there is not sufficient data related with the progression of myeloid malignancy. By using fluorescence in situ hybridization analyses, a critical region on the locus 7q22 and 7q34-36 have been observed in patients with MDS and AML associated monosomy 7 [7,11,12]. Recently, with polymorphic markers, commonly deleted interval on 7q22-31 have been searched and three distinct loci have been noticed [13]. In these locations, the candidate tumor suppressor gene(s) has been proposed; however, a distinct tumor suppressor gene(s) has not been found yet.

Because there is very few data whether monosomy 7 is () 1999 Wiley-Liss, Inc. related with parental origin, the aim of the present report is to investigate if monosomy 7 shows parent-of-origin in a child with MDS.

\section{MATERIALS AND METHODS}

A 4-year-old female child with de novo monosomy 7 and MDS was the subject of this study. The diagnosis of MDS was based on the criteria established by the French/ American/British (FAB) Cooperative Study Group [14].

\section{Cytogenetic Study}

Bone marrow (BM) cells of the patient and peripheral blood (PB) cells from both parents were examined. The karotype of patient was determined at the time of diagnosis and 6 months later by standard G-banding methods, and cytogenetic abnormalities were described according to the International Standing Committee on Human $\mathrm{Cy}-$ togenetic Nomenclature (ISCN, 1995) [15].

*Correspondence to: Dilek Aktas, M.D., Ph.D., Department of Genetics, Hacettepe University, Ihsan Dogramac1 Children's Hospital, 06100 Sihhıye, Ankara, Turkey. E-mail: daktas@genetic.gen.hun.ed

Received for publication 29 August 1998; Accepted 5 May 1999 
Telomere

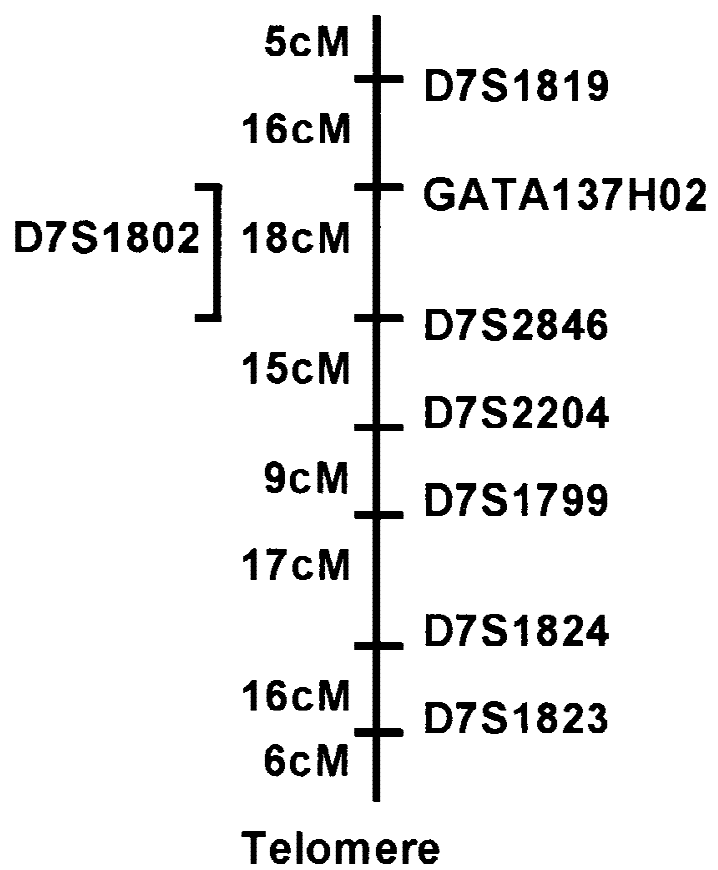

\section{Chromosome 7}

Fig. 1. The order of the markers on chromosome 7 is shown on the figure. The markers used in this study are illustrated on the right and left side of the vertical line. The genetic map was built on using the information in Genomic Data Base (GDB; http://www.gdb.org); Cooperative Human Linkage Center (CHLC; http://www.chlc.org) and comprehensive genetic maps in The Center For Medical Genetics, Marsfield, U.S. (http://www.marsmed.org/genetics).

\section{DNA Extraction and PCR-Based \\ Polymorphism Analysis}

DNA samples from patient BM cells and from both parents PB cells were prepared as described previously [16]. Polymerase chain reaction (PCR) markers used to determine the parental origin of our patient. The information on the order of these markers were obtained from previously published genetic linkage maps [1719]. The map order of the markers used and the cM intervals between the two adjacent loci were as follows: Telemore-(5cM)-D7S1819-(16cM)-GATA137H02(18cM)-D7S2846-(15cM)-D7S2204-(9cM)-D7S1799(17cM)-D7S1824-(16cM)-D7S1823-(6cM)-Telomere (Fig. 1).

Amplification was performed in a $25 \mu \mathrm{l}$ reaction mixture containing $1 \times$ PCR buffer, 100 ng of target DNA, 10 pg of each primer, $50 \mu \mathrm{M}$ of dNTPs, $2.5 \mathrm{mM} \mathrm{MgCl}_{2}$ and $1 \mathrm{U}$ of Tag polymerase (Perkin-Elmer Cetus, Emeryville, CA). Amplifications were carried out by MJ Research PTC-200 peltier thermocycler. An initial denaturation at $94^{\circ} \mathrm{C}$ for 2 min was followed by a two-cycle PCR amplification of $94^{\circ} \mathrm{C}$ for $30 \mathrm{~s}$ duration and $55-57^{\circ} \mathrm{C}$ annealing temperature for a total of 30 cycles. The amplified products were separated by electrophoresis on $6 \%$ denaturing polyacrylamide gels and the bands were visualized after silver staining [20] and manually photographed.

\section{RESULTS}

Cytogenetic analysis from BM cells of the patient revealed 45,XX, -7/46,XX mosaicism. Monosomy 7 was observed in 54\% of metaphases at the time of diagnosis. Unfortunately, the patient did not respond to chemotherapy. Six months after initiation of treatment, the repeated cytogenetic study revealed monosomy 7 in $86 \%$ of metaphases. The karyotypes of parents were normal.

We favored eight PCR markers from telomere to telomere on chromosome 7 for investigating loss of parent origin. All markers were informative on chromosome 7. Loss of maternal alleles was found and mitotic recombination was not observed. Maternal allele loss with D7S1824, GATA137H02, D7S1802, D7S1823 PCR markers was shown in Figure 2.

\section{DISCUSSION}

Monosomy 7 is a nonrandom cytogenetic abnormality in children with MDS and AML. Monosomy 7 has been reported in about $10 \%$ of de novo MDS [6,7] and this association mostly described in boys.

Parental origin of chromosome 7 in children with sporadic monosomy 7 has been investigated very rarely $[21,22]$. Three maternal and 7 paternal alleles have been reported by Katz et al. [21], and in the other study, 8 maternal and 4 paternal allele lost have been described by Savage et al. [22]. The results of these series have shown that the ratio of maternal to paternal chromosome loss in sporadic monosomy 7 cases was 1 -to- 1 . In the present study, allele loss on chromosome 7 has been evaluated in a female child with de novo monosomy 7 and MDS, and loss of maternal allele was observed by using eight polymorphic markers. In previous studies, maternal allele loss has been found in only 1 out of 4 female children evaluated $[21,22]$.

Imprinting has also been searched in patients with familial monosomy 7 [10,23]. One maternal, 4 paternal and 1 allele lost of both parents have been observed in familial monosomy 7 cases. When datas of familial cases are combined with results of sporadic monosomy 7 , there was not an important difference between number of cases with paternal and maternal allele losses. However, the number of patients analyzed is not sufficiently large enough for providing this consideration.

Monosomy 7 contributes to leukemogenesis because it results in loss of function of a critical gene(s) located on 


\section{D7S1824}

\section{GATA137H02}

D7S1802

\section{D7S1823}
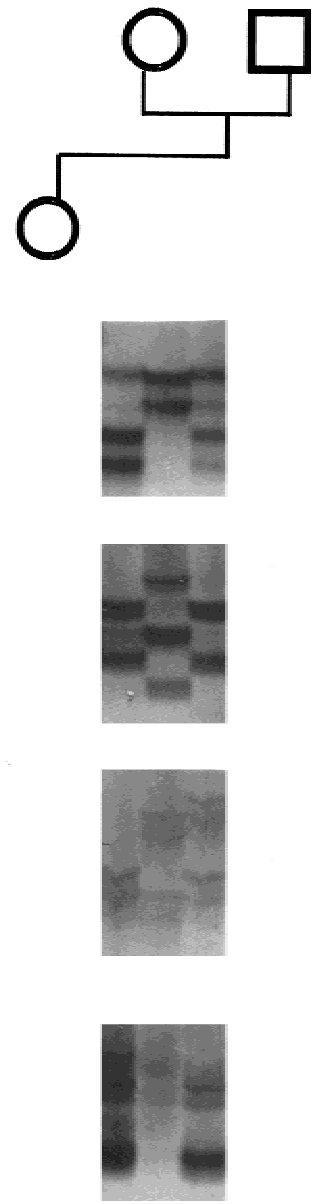

Fig. 2. Allele loss on chromosome 7 in a girl with MDS and monosomy 7. DNA from patient in line 1 , her mother in line 2 and father in line 3 is shown. Maternal allele loss with D7S1824, GATA137SH02, D7S1802, and D7S1823 PCR markers is seen.

long arm of chromosome 7. However, it is not known if functional inactivation of both alleles of a putative tumor-suppressor gene(s) is an essential step in leukomogenesis in monosomy 7. Despite the imprinting effects have been identified in a number of pediatric cancers, no direct evidence for imprinted gene in leukomogenesis has been observed. Studying parents-of-origin in all cases with de novo monosomy 7 might help to clarify the mechanism of leukomogenesis in this syndrome.

\section{REFERENCES}

1. Martinez-Climent JA. Molecular cytogenetics of childhood hematological malignancies. Leukemia 1997;11:1999-2021.

2. Hann IM. Myelodysplastic syndromes. Archives of Disease in Childhood 1992;67:962-966.

3. Creutzing U, Cantu-Rajnoldi A, Ritter J, Romitti L, Odenwald E, Conter V, Riehm H, Masera G. Myelodysplastic syndrome in childhood. Report of 21 patients from Italy and West Germany. Am J Pediatr Haematol Oncol 1987;9:324-330.

4. Tuncer MA, Paglucia A, Hicsonmez G, Yetgin S, Ozsoylu S, Mufti
GJ. Primary myelodysplastic syndrome in children: the clinical experience in 33 cases. Br J Haematol 1993;82:347-353.

5. Luna-Fineman S, Shannon KM, Lange BJ. Childhood monosomy 7 : epidemiology, biology, and mechanistic implications. Blood 1995;85: 1985-1999.

6. Flactif M, Lai JL, Preudhomme C, Fenaux P. Fluorescence in situ hybridization improves the detection of monosomy 7 in myelodysplastic syndrome. Leukemia 1994;8:1012-1018.

7. Le Beau MM, Espinosa R, Davis EM, Eisenbart JD, Larson RA, Green ED. Cytogenetic and molecular delineation of a region of chromosome 7 commonly deleted in malignant myeloid disease. Blood 1996;88: 1930-1935.

8. Laver JH, Yusuf U, Cantu ES, Barredo JC, Holt LB, Abboud MR. Transient therapy-related myelodysplastic syndrome associated with monosomy 7 and 11q23 translocation. Leukemia 1997;11:448-455.

9. Maris JM, Wiersma SR, Mahgoub N, Thompson P, Geyer RJ, Hurwitz CG, Lange BJ, Shannon KM. Monosomy 7 myelodysplastic syndrome and other second malignant neoplasms in children with neurofibromatosis type 1. Cancer 1997;79:1438-1446.

10. Shannon KM, Turhan AG, Chang SSY, Bowcock AM, Rogers PCJ, Carroll WL, Cowan MJ, Glader BE, Eaves CJ, Eaves AC, Kan YW. Familial bone marrow monosomy 7. J Clin Invest 1989;84:984-989.

11. Johnson EJ, Scherer SW, Osborne L, Tsui LC, Oscier D, Mould S, Cotter FE. Molecular definition of a narrow interval at 7q22.1 associated with myelodysplasia. Blood 1996;87:3579-3586.

12. Johnson EJ, Cotter FE. Monosomy 7 and 7q-associated with myeloid malignancy. Blood 1997;11:46-55.

13. Liang H, Fairman J, Claxton DF, Nowell PC, Green ED, Nagarajan L. Molecular anatomy of chromosome 7q in myeloid neoplasms: Evidence for multiple critical loci. Proc Natl Acad Sci USA 1998;95: 3781-3785.

14. Bennett JM, Catovsky D, Daniel MT, Flandrin G, Galton DAG, Gralnick HR, Sultan C. Proposals for the classification of the myelodysplastic syndrome. Br J Haematol 1982;51:189-199.

15. ISCN 1995. Guidelines for cancer cytogenetics. In: Mitelman F, ed. Supplement to an international system for human cytogenetic nomenclature. Basel: Karger, 1995.

16. Miller SA, Dykes DD, Polesky HF. A simple salting out procedure for extracting DNA from human nucleated cells. Nuc Acid Res 1996;16: 1215.

17. UTAH Marker Development Group. A collection of ordered tetranucleotide-repeat markers from the human genome. Am J Hum Genet 1995;57:619-628.

18. Scheffield VC, Weber JL, Buetow KH, Murray JC, Even DA, Wiles K. A collection of tri- and tetranucleotide repeat markers used to generate high quality, high resolution human genomwide maps. Hum Mol Genet 1995;4:1837-1844.

19. Dib C, Fayre S, Fizames C, Samson D, Drouot N, Vignal A, Millasseau P, Marc S, Hazan J, Seboun E, Lathrop M, Gyapay G, Morissette \& Weissenbach J. A comprehensive genetic map of the human genome based on 5264 microsatellites. Nature (London) 1996;380:152-154.

20. Aktas D, Ayhan A, Tuncbilek E, Ozdemir A, Uzunalimoglu B. No evidence for overexpression of the 553 protein and mutations in exons 4-9 of the p53 gene in a large family with adenomatous polyposis. Am J Gastroen 1998;93:1524-1526.

21. Katz F, Webb D, Gibbons B, Reeves B, McMahon C, Chessels J, Mitchell C. Possible evidence for genomic imprinting in childhood acute myeloblastic leukemia associated with monosomy for chromosome 7. Br J Haematol 1992;80:332-336.

22. Savage P, Frenck R, Paderange D, Emperor J, Shannon KM. Parental origins of chromosome 7 loss in childhood monosomy 7 syndrome. Leukemia 1994;8:485-489.

23. Shannon KM, Turhan AG, Rogers PCJ, Kan YW. Evidence implicating heterozygous deletion of chromosome 7 in the pathogenesis of familial leukemia associated with monosomy 7 . Genomics 1992;14: $121-125$. 